\title{
ОСВІТА ЯК ДИВО І РОЗЧАКЛОВАНА РЕАЛЬНІСТЬ
}

\author{
Култасва М. Д. \\ доктор філософських наук, професор, член-кореспондент НАПУ України, \\ завідувач кафедри філософії, співробітник науково-методичної лабораторії \\ духовно-інтелектуального виховання та навчання, \\ Харківський національний педагогічний університет імені \\ Г. С. Сковороди, м. Харків, Україна,
}

У статті обтрунтовується необхідність розрізнення опиій бажаного, можливого і реального у визначенні перспектив розвитку освіти, передусім це торкається духовно-інтелектуального виховання $і$ навчання у постіндустріальному суспільстві. Аналізується європейський досвід діагностики культурних патологій $і$ деформацій, щзо супроводжують циифровізацію освітніх практик.

Ключові слова: освіта, цчифровізація, навчання, виховання, культурні патологї.

The article proposes an explanation of the essential distinction between wishful, possible and real options assigning the perspectives for the development of the education, what is especially important for spiritual and intellectual learning in the conditions of the postindustrial society. The European experience of the diagnostic of the cultural pathologies and deformations is analyzed as some side effect of the digitalization.

Key words: education, digitalization, learning, forming, cultural pathologies.

Поза усяким сумнівом, освіта є дивом і сама творить дива, змінюючи людину і світ навколо неї. Освічена людина, це просвітлена людина, вона випромінює світло розуму, а їі життєвий шлях, проторований активними і пасивними учасниками цивілізаційного процесу ще здавна визначався як via lucis — шлях світла. Цей пронесений крізь віки сакральний і романтизований образ освіти є джерелом натхнення також і для сучасної людини.

Не заперечуючи мобілізуючу значущість цього образу та його внесок до суспільного визнання високої місї̈ освіти як чинника гуманізації суспільства, треба зазначити, що він втілює контрфактичний модус репрезентації освіти в опціях бажаної і вимріяної перспективи людства. Але бажаний, можливий і дійсний стани освіти, як також суспільства і культури, мають принципові відмінності, які треба ураховувати у 
Розділ І. Ціннісні орієнтири духовно-інтелектуального виховання, розвиток духовно-інтелектуальних якостей особистості в умовах співпраці й інклюзії

стратегіях реформування сучасної освіти, що далеко не завжди береться до уваги пристрасними реформаторами освітніх інституцій та практик навчання і виховання.

Гасла на зразок «Освіта для майбутнього» або «школа для майбутнього», які лунають на тільки в Україні, а й на європейських теренах, гонитва за інноваціями нерідко виявляються дуже відірваними від тих реалій, де функціонують національні освітні системи. Зокрема, німецькі теоретики вважають, що причиною тому є некритичне ставлення до американського досвіду у галузі реформування освіти. Як зазначає Юліан Ніда-Рюмелін, моноцентрична орієнтація європейських освітніх культур на США маргіналізує Свропу як ціле, а через політику щодо науки несе загрозу європейській інтеграції. Свропейська наукова і освітня традиція є багатою, ... вона здатна конкурувати 3 американською» [5, с. 169-170].

Разом $з$ цим треба зазначити, що цифровізація культури і суспільного життя у цілому вимагають їхнього оновлення. Але гіпотетичне перетворення сучасної людини на homo digitalis у поєднанні з homo creator у дійсності може мати небажані наслідки, бо гібридизація цих орієнтирів криє у собі ризики появи патологій у розвитку особистості, стимулювати кримінальну креативність, особливо у незаможних суспільствах. Це впливає також та педагогічне мислення і педагогічні практики. Ю. Харарі слушно застерігає від пов'язаних з цим патологій педагогічного експериментування: «До недавнього часу усі сходились принаймні в одному: для покращення освіти треба змінювати школу. Але сьогодні уперше в історії ми віримо, що, мабуть, більш ефективною була би зміна біохімії учнів» [2, с. 59]. Цифрова субкультура певною мірою сприяє такій аберації індивідуальної і суспільної свідомості.

В останні десятиліття слова «креативність» та «інноваційність» стали не тільки недоторканим осердям ідеології постіндустріалізму та трендом інтелектуальної моди. Вони перебирають на себе функцію критерію оцінювання людських дій та якостей, сприяючи тим самим ствердженню суб'єктивізму. Особливо це притаманно посткомуністичним країнам з успадкованою від СРСР манією навішувати на будь-які продукти, включно з духовними, знаки якості, створювати імітації реформ і впроваджувати експортований «передовий досвід». Суспільна свідомість таких транзитивних суспільств наповнена сподіваннями на краще життя і тому охоче сприймає і генерує рецепти чудодійного 
і швидкого стрибка із злиднів до добробуту. Цифрова культура підкріплює такі ілюзії. Прихована редукція homo Deus до homo digitalis, яка відбувається у сучасному медійному просторі, відповідає таким мріям і пафосу оновлення, рекламуючи сама себе. Але при цьому вона спонукає пересічну людину і політиків до дій, мобілізує їх на досягнення начебто недосяжного, на само перевершення в обмежених умовах існування. Водночас людина, яка об'єктивно прив'язана до цифрових технологій, суб'єктивно підганяє під них свою сенсорику і техніки мислення, вибудовуючи свою унікальність 3 матеріалів серійного виробництва масової культури.

В описах сучасників масштабні інновації завжди зустрічались 3 недовірою. Не винятком $є$ й ставлення до постіндустріальної культури, хоча застереження iĭ критиків варто взяти до уваги. Так, цифровій освіті скептики передрікають швидкий і безславний кінець на зразок того, як у 70-х рр. виявились «неефективними лінгвістичні лабораторії та програмоване навчання», на яке у Німеччині виділялись значні кошти [7, с. 13]. Змішане навчання (blended Learning) як гібридна форма інтенсифікації навчального процесу також є предметом прискіпливого розгляду з боку прихильників західноєвропейської провокативної філософії освіти. Вони звертають увагу на те, що «цифровізація» класних приміщень на аудиторій нерідко є самоціллю, ознакою нібито успішного проведення освітніх реформ. Тиск з боку политиків знаходить прояв у прихованому примусі пришвидшувати впровадження цифрової освіти незалежно від наявних ресурсів. Голоси ж з протилежного табору намагаються переконати громадськість у зворотному. Наведемо їхню аргументацію: «Комп’ютери і смартфони шкодять освіті. Ані німецькі, ані міжнародні дослідження поки ще не довели позитивного впливу комп’ютерів та Інтернету на навчання у школі. І навпаки, їхній негативний вплив чітко простежується. Аналіз даних PISA, зібраних за десять років у більш, ніж 50 країнах, свідчить: чим більше грошей вкладається у цифрову інфраструктуру, тим швидше погіршується успішність учнів у такий країні» [3, с. 17]. Ще більш радикальне у дусі сучасних антиутопій висловлюється М. Шпітцер: «На підставі сучасних наукових досліджень комп'ютер необхідний для навчання так само, як ровер для навчання плавати або рентгенівський апарат для примірювання взуття» [7, с. 23]. 
Розділ І. Ціннісні орієнтири духовно-інтелектуального виховання, розвиток духовно-інтелектуальних якостей особистості в умовах співпраці й інклюзії

Своєрідним підсумком освітніх дискусій у європейському просторі можна вважати висловлювання К.П. Лісмана. Він слушно наголошує: «Освіта не $\epsilon$ катастрофою. Освіта також не $\epsilon$ релігією. I насамперед: освіта не вирішує усіх проблем. Ми багато б чого спромоглись, якби замість тривіальної суміші з освітніх мрій з риторикою менеджменту встановили можливості та межі шансів і ризиків, які криють у собі процеси, що відбуваються в освіті. Освітні установи зараз потребують не більше, а менше реформ, нехай це звучить парадоксально: у суспільстві, що змінюється прискореними темпами, системи освіти потребують уповільнення, не поспіху, а осмислення, стабільності, а не перманентних змін, захищеності, а не тривалої політичної та масмедійної канонади» [4, 29, див. також 6, с. 45].

У підсумку треба зазначити, що ігнорування дійсних умов розвитку і трансформації освіти спричинює у суспільстві появу культурних і соціальних патологій, які, в свою чергу виступають руйнівним чинником суспільного розвитку. Люмпенізація шкільних вчителів і університетських викладачів в Україні та інших регіонах Східної Європи також мало бентежить суспільну свідомість, занепокоєну пошуками чудодійних рецептів прискореної або, на крайній випад, наздоганяючої модернізації.

\section{Список використаних джерел:}

1. Hammermann A. Begehrte Tüftler. In: Uniglobale. Januar, 2020, S.22-24.

2. Harary J. Homo Deus. Eine Geschichte von Morgen. München:Beck, 2017. $536 \mathrm{~S}$.

3. Lembke Gerald, Leipner Ingo. Die Lüge der digitalen Bildung. Warum unsere Kinder das Lernen verlernen. München: Beck, 2015. 234 S.

4. Liessmann Konrad Paul. Theorie der Unbildung. Die Irrtümer der Wissensgesellschaft. — Wien: Paul Zsolnay Verlag. 2006. 275 S.

5. Nida-Rümelin Julian. Der Akademisierungswahn. Zur Krise beruflichen und akademischer Bildung. Hamburg: Körber-Stiftung. 2014. 253 S.

6. Norbert Klaus. Idioten. Made in Germany. Wie Politik und Wirtschaft Bildungsverlierer produzieren. — München: Knaur Taschenbuch Verlag, 2011. 384 S.

7. Spitzer M. Digitale Demenz. Wie wir uns und unsere Kinder um Verstand bringen . Hamburg: Dömner. 149 S. 